\title{
Life and the Technical Transformation of Différance: Stiegler and the Noo- Politics of Becoming Non-Inhuman
}

\section{This is an Accepted Manuscript of an article published in Derrida Today, available online: https://doi.org/10.3366/drt.2016.0132}

Abstract

Through a re-articulation of Derridean différance, Bernard Stiegler claims that the human is defined by an originary default that displaces all psychic and social life onto technical supplements. His philosophy of technics re-articulates the logic of the supplement as concerning both human reflexivity and its supports, and the history of the différance of life itself. This has been criticised for reducing Derrida's work to a metaphysics of presence, and for instituting a humanism of the relation to the inorganic. By refuting these claims, this article will show that Stiegler's doubling of différance enables him to articulate the human as constituted by both the individuation characteristic of 'life', and that of a technical, psychic and collective individuation. Putting forward a reading of the logic of the trace in life, and emphasising the aspects of Leroi-Gourhan, Simondon, and Canguilhem that Stiegler uses in his reading of Derrida, I will demonstrate that the political stakes of adaption and adoption in NooPolitics require this re-articulation of différance. Technics shapes the human future, arising from this differential mutation; marking the invention of the human as the site of the political.

Key Words; Stiegler, Derrida, Technics, Différance, Life, Noo-Politics

Word Count: 7,671 
Stiegler's initial encounter with Derrida in The Fault of Epimetheus is concerned with establishing the origin of the human as aporetic, defined by a lack of quality that is always supplemented by technical supports (Stiegler 1998). The larger aim of this critical engagement is to re-cast the origin of the human in the technical co-contamination of the transcendental and the empirical. What separates the human from life in general is the technical support of psychic and social (symbolic) individuations, related by a principle of différance, empirically and historically articulated. This has been criticised for reducing différance to the presence of an apparently 'pure' life outside of technics (Bennington 2000), and a humanism of the relation to the inorganic (Colony 2011). Instead, I will argue that Stiegler's doubling of différance enables him to articulate the human as constituted by both the individuation of life, and of psychic and collective individuation. Putting forward a reading of the logic of the trace as present in life, and emphasising the aspects of the work of André Leroi-Gourhan, Gilbert Simondon, and Georges Canguilhem ${ }^{i}$ that Stiegler uses in his reading of Derrida, I will demonstrate that Stiegler's political project of establishing a Noo-Politics requires this re-articulation of différance. This allows a consideration of the contemporary political use of Derridean concepts by Stiegler, that the adoption of new forms of human existence can be thwarted by the enforcement of adaption, eliminating the transformative dimension of the différance between the human and the technical. I will argue, therefore, that Stiegler's contribution to the politics of deconstruction should be understood in this light; he puts its concepts to work in the continual political construction of a human future.

\section{The Origin of the Human and the Rupture in Différance}

The key element that enables Stiegler to think this is the doubling of différance, to show that beyond spatialisation and temporalisation, a new form of différance emerges with the human: the co-constitution of the psychic interior and its technical and symbolic milieus. Technical objects are externalised forms of human memory, inscriptions in matter that support symbolic projections, and form 
shared social memory. Psychic interiority is the re-interiorisation of this pre-individual fund, as a différant transformation. For Stiegler, neither interior or exterior can be raised to the level of priority (Stiegler 1998: 152). Locatable only within the complex of being-in-default, human subjects are the product of an originary complication of interior and exterior, which structurally links technicity and the human psyche.

Stiegler is indebted to Leroi-Gourhan for this thesis, who argues that the defining traits of humanity (anticipation, the experience of temporality, and enhanced cognitive capacity) have a materialist rather than idealist basis. The claim that tools invented the human counters 'cerebralist' accounts that presuppose larger brain capacity in the development of tool use. Instead, hominisation began due to a re-arrangement of the pre-hominid skeleton which freed the hands for the manipulation of tools, in turn allowing for the expansion of the skull to accommodate increased cerebral growth (Leroi-Gourhan 1993: 26). Stiegler expands this argument to claim that human anticipation is structurally linked to technicity, its origin being in this necessary (and therefore transcendental) default. This transcendental condition is inaccessible outside of its empirical determination by historical forms of technical systems: 'there is a history of technological possibilities of anticipation - which is the history of the different mirror stages in which humanity reflects itself' (Stiegler 1998: 159). Stiegler utilises Leroi-Gourhan's argument to claim that there is no pre-existing human mirrored or extended by technics, but one constituted by it, where the subject is irreducibly linked to the historical technical object, and any investigation of this transcendental condition takes place from behind an empirical horizon (Lewis 2013: 61). This confounds the metaphysical resolution of the event of human origin, as such an investigation is constrained by it's historically contingent technical supports, on both the side of the investigator, and the investigated.

As such, the human is not the product of a biological phylum that has priority over the technical, but rather a complex and irreducible aporia between the technical and the biological. This forms the relation between psychic and social memory. Experience of the world, and our memories selected from this experience, are informed by technical facticity as externalised collective memory. These three forms of memory are linked by a relation of différance for Stiegler: the re-interiorisation of technically supported ideas is always a transformation of this material. There is always a translation 
by the individual in the adoption of collective forms of existence. Différance marks this particular organisation of differentiation as 'the pursuit of the evolution of the living by other means than life', where the absolutely singular individual adoption or interiorisation of nonliving memory is conditioned by its shared facticity (Stiegler 1998: 135). The object of thought is formed in the relationship between individual retentions, social retentions and technically supported retentions, an organisation made possible by the aporia of the structural coupling between cerebrality and technicity (James 2013). This requires a transformation of what Derrida initially put forward under the term différance, in order to articulate a difference between this human form of individuation, and the spatialisation and temporalisation of life itself. ${ }^{\text {ii }}$ Stiegler's return to Leroi-Gourhan, a key reference point in Of Grammatology, allows him to claim that something absolutely new occurs in the emergence of the coupling between the human and the technical. This is the doubling of différance, which separates a technical form from its general character 'which is nothing else than the history of life itself', in order to show that it is the co-constitution of the human and technics that puts the unity of humanity into disrepute (ibid 136). The appearance of humanity and technicity is conditioned upon a transformation of the logic of arche-writing which pre-exists them, opening up the horizon of the adoption of new forms of technical différance.

By referring back to Leroi-Gourhan on this coupling, Stiegler argues that he can resolve a tension that he alleges exists in parts of the Derridean corpus on différance. On the one hand, as stated, it is: 'temporization [that] is also temporalization and spacing, the becoming-time of space and the becoming-space of time' (Derrida 1972: 8). As 'differentiation and deferral, a spacing of time and a temporalization of space', it refers to 'life in general...[that] there is time from the moment there is life' (Stiegler 1998: 138-9). Such an assertion is the reason why grammatology cannot be reduced to 'one of the sciences of man', for the naming of man is predicated upon the 'graphie in general...as a stage or articulation in the history of life...the history of the grammē' (Derrida 1976: 83-4). It is this 'stage' that Stiegler mobilises to draw conclusions from another passage: 'the trace is the differance which opens appearing and signification. Articulating the living upon the non-living in general, origin of all repetition' (ibid 65). That is, there is 'an emergence that makes the grammē appear as such', 
which we 'cannot think... without the most general concept of the grammē' (ibid 84). ${ }^{\text {iii }}$ There is a separation between the grammē as a general logic of all life, and the 'as such' of the human stage, that articulates the appearance of this difference to the understanding.

Whether this is a faithful reading of 'Différance' and Of Grammatology is not the issue at stake here. Rather, it is the manner in which Stiegler transforms différance through his adoption of it. This adoption asserts the existence or appearing of a new stage; the inscription of the living onto the nonliving which constitutes the human default of origin, opening up the noetic capacity that makes the very thought of différance possible. There is a passage from différance as 'pure physis', to the thinking of this logic through technics that constitutes a slippage in Derrida's work that '[remains] to be thought' fully (Stiegler 1998: 139). Originary prostheticity marks the passage from a general logic of deferral, one that is "[o]lder" than Being itself' (Derrida 1972: 26), to the human articulation of memory retentions onto the non-living which makes the very thought of Being possible. This means that the human, as a mode of Being, is unthinkable in its purity, and must be thought as a history of its forms. As human thought, for Stiegler, is conditioned by this technical horizon, différance can only be conceptually rendered within an archaeology of the relationship between technics and psychic interiority, meaning it is articulated historically, rather than quasi-transcendentally. This project is one that Derrida announced in the 'history of supplement' but 'did not himself ever carry out' (Stiegler 2013a: 167). Différance has 'no unique name' (Derrida 1972: 27); for Stiegler this is because it has many names, articulated both as the general differentiation of space and time, and according to a history technical supports.

Stiegler's resolution of this hesitation that he sees in Derrida's work on différance requires thinking technics as epiphylogenesis, a third form of memory that supplements those already found in life: genetic and epigenetic memory. Différance as life in general is doubled, in order to claim that human technicity is an escape from the non-intentional movement of différance in biological evolution, into an evolution by the intentional manipulation of inorganic supports. This amounts to the preservation and subsequent adoption of the experience of others: 'the conservation, accumulation, and sedimentation of successive epigeneses' (ibid 140). Whereas individual experience in other 
species is lost in death, or conserved only in genetic modifications and natural selection (as nonconscious species level memory), the human can transmit individual experience to others, a preservation which constitutes culture, history, and ethnic differentiation. In Stiegler's words, 'epiphylogenesis is a break with pure life, in that in the latter, epigenesis is precisely what is not conserved' (Stiegler 1998: 140). This inaugurates a difference between adaption and adoption which is central for Stiegler's politics, as we will see. Crucially, his argument pivots on the claim that this break is a transformation of différance from within a technical horizon that makes thought possible.

\section{Différance as the Arche-Writing of Life}

Geoffrey Bennington, however, has claimed that this means that Stiegler reduces life to presence and technics to positivity (Bennington 2000: 162-179) ${ }^{\text {iv }}$ He takes issue with the articulation of an archaeological history of the incarnations of différance, following a rupture with 'pure' life, that does not fall into a positivism of technics. Bennington summarises: 'Stiegler is taking over from Derrida a certain generalised structure... which he is on the one hand appropriating' as technics, and therefore as 'the passage from the genetic to the non-genetic and thereby from the animal to the human' (ibid 169). After noting that this appropriation relies on highlighting an inconsistency in différance, four key points in Stiegler's use of Derrida are put forward: 1) he assumes that différance as 'life in general"...is a general definition', 2) he '[identifies] life with physis', 3) assumes that 'the emergence of "intentional consciousness" [is] the appearing of an "as such" of the gramme [that] must be thought of as a break', and 4) is 'surprised to find différance on both sides of such a presumed break' (ibid 170-1). The fault in Stiegler's series of suppositions is that 'physis is or could be a pure presence subsequently affected by différance', whereas différance shows that 'no concept can attain to the value of "presence", and that this situation is (logically) originary' (ibid 171). Not only is life placed into a position of presence, but it is opposed to technics: Stiegler 'force[s] the whole philosophical argumentation of Derrida through the "passage" of the emergence of mankind' which 'commits him 
to a certain positivism about difference' (ibid). These criticisms force us to consider how an understanding of différance as life in general does not reduce it to pure presence. Against Bennington's reading, this can be asserted through the already existing relationship between deconstruction and life that is built upon by Stiegler's use of the work of Leroi-Gourhan, Simondon, and Canguilhem.

'There is différance before as after the anthropological rupture' (Stiegler 2009: 157). This statement suggests, in opposition to Bennington, that two forms of différance can be separated without abstracting the human from life. Clarity on this point can be found by returning to Derrida to show how life itself is characterised by différance, but also how Stiegler supplements such a view with the notion of different regimes of individuation to be found in Simondon. Francesco Vitale has recently claimed that Derrida supported the view that: 'differance [is] the irreducible and structural condition of the life of the living' (Vitale 2014: 96). For Vitale, the conjunction of biology and cybernetics allowed Derrida to provide a definition of life that 'is regulated by the possibility of elaborating iterable traces', a capacity which is 'prior to the opposition between man and the animals', which means that 'the animal in general must be endowed with a structure of retention and protention and, thus, must be capable of memory' (Ibid 103). Through his reading of Derrida's unpublished seminar on the work of biologist François Jacob, entitled La Vie La Mort, Vitale shows that the structure of the trace and the necessity of iteration through reproduction goes all the way down to the very conditions of life in DNA; '[t]he living structures itself as a system of arche-writing, as the retention, elaboration and protention of a weave, a tissue of traces, namely, as a text' (ibid 110). Life is a weave of traces that constantly displaces itself onto supplementary parts:

'the sense of the genetic message does not depend on its alleged content but on the order of combination of the elements, which produces a sequence of interactions in the cell. Every element taken by itself does not produce any effect, precisely as the letter of the alphabet has no meaning in itself' (ibid 107-8).

The irreducibility of this reproduction to presence, situates imperfection as différance at the heart of life. 
There is nothing in Stiegler's work to suggest that he would dissent from this definition of life as différance. His use of the term 'pure' to designate life is a strategic highlighting of the specific difference of the human form of differentiation, that technical systems are utilised to counter the dissolution at work in différance. This relationship between the human and the technical institutes a new form of what Simondon refers to as a regime of individuation. Importantly, Stiegler asserts that différance must in fact be thought of today in terms of individuation (Stiegler 2015c: 63). Simondon argued that individual entities should be understood not from their unity, but from the perspective of a complex, and ongoing process of production, where stability is a surface effect of an ongoing ontogenesis (Simondon 2009: 5). What is key is that within these processes of individuation a final state is always deferred, as individuals are formed in a transductive relation to other individuals (Stiegler 2011a: 38-9). This allows one to distinguish between different regimes of individuation, without reifying differences between them.

Simondon identified three forms of individuation: the physical, the vital, and the psycho-social. What is important here, is that the regime of vital individuation proceeds by forming what Simondon called 'metastabilities', the difference in metastability between the living and the human being what marks the doubling of différance. A metastability is an apparent and temporary form of stability that is 'capable of evolving...alive with the contradictions and differences' it has hitherto been part of (Chabot 2013: 102). Simondon applies this definition to the individuation of life:

'the living conserves within itself a permanent activity of individuation. It is not only the result of individuation, like in the case of the crystal or the molecule, but it is the theater of individuation...[w]ithin the living itself, there is a more complete regime of internal resonance, one that requires permanent communication and that maintains a metastability that is a condition of life' (Simondon 2009: 7).

The metastability of the living is constituted by a permanent re-production and establishment of a resonance between components, an arche-writing that means no single element constitutes the totality of the system of living individuation, and that unity is always deferred onto a supplementary 
element. Conjoining Derrida and Simondon, Stiegler argues that life is the autoimmune process by which unity and stability are deferred, but through the reproduction and the différant co-articulation of its elements, attempts to remain stable. Life as différance, or autoimmune process, is an individuation process that forms metastabilities, and therefore constant transformations that are 'driven towards upholding the system in its greatest potentiality' (Stiegler 2014a: 194). ${ }^{\vee}$ What Stiegler wishes to argue is that for the human there is something else at work; the deliberate manipulation of how these metastabilities are produced, through the co-constitution of human and technical life. Simondon allows Stiegler to combine the thought of deferral at work in différance with the notion of differentiated regimes of this logic found in the notion of individuation (Ross 2013: 245).

The ability to resist the autoimmune tendency by forming metastabilities can be understood as the ability to resist shocks from an organism's environment. Stiegler turns to Canguilhem to think this. In the latter's terms: 'life is not a monotonous deduction, a rectilinear movement...it is discussion...with an environment where there are leaks, holes, escapes and unexpected resistances' (Canguilhem 1991: 198). It 'is experience, that is to say, improvisation, the utilisation of occurrences' that the living organism must use in order to preserve itself (Canguilhem 2008: 90). In Stiegler's summary; 'life is a process and, in the course of life, life-forms stabilize themselves' (Stiegler 2013b: 28). What is key, however, is that while it is conceived as a form of memory in Derrida's reading of Jacob, there is no intentionality in this process at a general level. This is Jacob's central axiom: 'the programme cannot receive lessons from experience' (Jacob 1974: 11). ${ }^{\text {vi }}$ The organism's genetic programme resists shocks from the environment, which for Canguilhem is a 'margin of tolerance for the inconstancies of the environment' (Canguilhem 1991: 197). Those that can persist in a particular milieu and its variability, or infidelity, are able to reproduce through what is essentially 'accidental survival' (Moore 2013: 20-21). Jacob's axiom, once submitted to this deconstructive reading, refers to the differentiation of the genomic in the way it adapts to these inconstancies, but not through the intentional activity of the organism. As Vitale summarises, his 'recourse to the text as a model for describing the logic of the living is not accidental: the text imposes itself because of the very nature of living', a nature that is defined by the logic of the trace (Vitale 2014: 108). ${ }^{\text {vii }}$ Survival, adaption, 
and the production of normative activity is always a transformation of the metastable set of potentials that constitute this woven text of life.

It would be foolish to deny that the human is not subject to this différance of life. What separates the human from the living is that the relationship of the individual to its milieu is sutured by the technical supplement. Stiegler's reference to Canguilhem supplements his reading of Derrida through Leroi-Gourhan and Simondon on this point. The human is able to resist the autoimmune tendency towards destruction that is internal to life through the technical extension of the body, which moves normativity from the level of the organism to the relationship between the organism, the technical, and the social. Human individuation or différance produces metastabilities through its technical supports. But this also means that the threats to individuation are different to that of life. What Canguilhem refers to as the pathological, or the inconstancies of the environment, are not derived merely from the externalities that impinge on the organism, but from artificial technical supplements themselves:

'we cannot clearly understand how the same man with the same organs feels normal or abnormal at different times in environments suited to man unless we understand how organic vitality flourishes in man in the form of technical plasticity' (Canguilhem 1991: 201).

A new 'infidelity of the milieu' arises from the transformation of différance in the establishment of a new regime of individuation, induced by a re-articulation of the production of normative metastabilities through the deliberate adoption of techniques, rather than adaption to natural selection (Stiegler 2013b: 29). The transformation of différance that Stiegler wants to effect is this materialisation, and therefore differentiation and historicisation, of the quasi-transcendental logic of deferral. It is his use of Leroi-Gourhan, Simondon, and Canguilhem that enables him to do this, for they allow him to define différance at both the level of the organic, and the inorganic adoption of norms.

This means that the possibility for the preservation of experience is found in the structural coupling between the human and the technical, which re-articulates the logic of différance at work in life in general. While it is still within this general logic of autoimmunity, the human is capable of preserving 
its experience beyond the differentiation of the genetic program, and passing this on across generations. This opens up noetic capacities without opposing them to a pure understanding of life. Simondon states this continuity as follows:

'Being as subject and being as object arise from the same primitive reality, and the thought that now appears to institute an inexplicable relation between object and subject in fact prolongs this initial individuation; the conditions of possibility of knowledge are in fact the causes of existence of the individuated being' (Simondon 2005: 127, cited in Combes 2013: 7-8).

The knowing subject emerges from the same pre-individual milieu as vital individuation, as a different kind of normative activity between the human and this milieu, which is constituted by technical objects. There is a transformation of différance that occurs with the re-structuring of the human environment by non-genetic forms of memory, opening up the expansion of cerebral activities and the prolonging of normativity beyond the autoimmunity of life itself. Where Derrida states that 'the revenant, between life and death, dictates an impossible mourning, an endless mourning - life itself' (Derrida 2005a: 35), Stiegler argues that the technical threshold established between human life and death re-articulates this spectral logic in a different manner.

\section{The Positivism of Technics and the Problem of Inorganic Privilege}

Even if physis, or life itself, is not subjected to presence, something achieved through Stiegler's connection of Leroi-Gourhan, Simondon, and Canguilhem to différance, what of the technical sedimentations that allow the constitution of the human? Colony criticises Stiegler on the grounds of a positivism of the human-technics coupling that sees 'nonhuman life.... in universal terms', and therefore 'overlooks...the fact that nonhuman life as différance was always already articulated by a relation to inorganic materiality and, thus, by what is other to life' (Colony 2011: 84-5). ${ }^{\text {viii }}$ What Stiegler overlooks by separating nonhuman and human life by way of the default of origin, is that différance asserts that nonhuman temporality is already related to the inorganic, and does not exist within a homogenous temporality of its own (ibid 86-7). Moving forward from Bennington's critique, Colony 
claims that the organological constitution of the human is 'pervasive[ly] anthropocentric', despite its 'challenge' to those humanisms that would simply fix 'the essence of the human in a traditional metaphysical determination' (ibid 88). Taken together, these criticisms suggest that Stiegler's humanism consists grants the human privileged access to the pursuit of life by inorganic means, which is in turn reduced to a positivistic knowledge.

This 'humanism' is not as crude as it first appears for two reasons. First, while originary for the human, technicity is not restricted to it in principle, as it is the technical tendency itself that invents the human. Second, this means that the human is caught between two pharmacological tendencies, one curative, the other poisonous. ${ }^{\mathrm{ix}}$ The vector of hominisation is curative, allowing access to noetic capacities, but it is inextricably linked to a tendency towards regression, as it is still caught within the arche-writing of the biological. This can be thought with adoption and adaption, the former referring to the content transformation of the human by its adoption of technical supports, the latter referring to the emptying of any singularisation from this process. By doubling différance and placing the human within both of its logics, Stiegler forces us to think a politics which is only a humanism to the extent that it problematises the constant redefinition of becoming non-inhuman in adoption, against the tendency to regress to inhumanity in adaption.

We have already seen that the différance of life involves an articulation with the inorganic, through the relation of the arche-writing of DNA and the metastabilities this forms in tandem with an environment. The key to showing that Stiegler's work is not naively humanist is to see the technical as a tendency which invented the human, in an unlocatable rupture that transformed the relation between pre-hominids and their milieu. Stiegler writes: 'the appearance of the human coincides with a sudden hegemony of the epiphylogenetic within the developing process of differentiation. "The human" is precisely this hegemony' (Stiegler 2009: 161.) Epiphylogenesis is a tendency that composes with other tendencies: 'the technical dynamic precedes the social dynamic and imposes itself thereupon' (Stiegler 1998: 67). Understanding the technical dynamic as prior to the human means that the pursuit of life by inorganic means is in no way an a priori privilege. Instead, as lan James 
has summarised, 'a logic of technicity precedes the human, and that only on the basis of this precedence does it then come to constitute the human as a hegemonic but by no means exclusive regime of the technical' (James 2010: 214). This tendency is still present within the life of other organisms, but not to the same extent. With this clarification, we can see in a more precise light the difference between the two regimes of différance: the first mode consists of tendencies that are autoimmune, individuation processes defined by adaption to environmental pressures which may involve the use of, but not evolution via, the technical. The second, following the rupture of hominisation, marks a hegemony of technical tendencies over human life, allowing the pursuit of evolution through inorganic means, and therefore its adoptive capacities. Both human and nonhuman life are composed of tendencies that are inseparable from the forces with which they compose and decompose differentially, forming different regimes of individuation (Stiegler 2011a: 58-61). What marks out the human, is a pre-dominance of the technical tendency, and therefore the capacity for noetic, adoptive activity, rather than a restriction of this tendency to the human over other forms of life.

Despite this break with the prior logic of différance, these human tendencies are not free from the spectral grasp of deferral, and are irreducible to a positivism. This is because the technical invention of the human occurs within a 'system of constraints... a play of limits... a combination of forces' that 'frees ever-new possibilities - in this sense [it] invents them' (Stiegler 1998: 75). The human does not simply wield the technical, rather, it's possibilities are forged by technics. Epiphylogenesis frees up the possibility of new processes of individuation, supported by technical milieus, but these individuation processes are irreducible to knowledge understood as pure positivity because they are formative of knowledge. The co-becoming of psychic and technical individuations, and the collective individuations they support, means that knowledge only ever emerges from adoption, and therefore transformation.

This threefold articulation, between the technical, the psychic, and the social, which Stiegler refers to as General Organology, is a regime of différance that co-implicates the terms involved (Stiegler 2014b: 5). Derrida refuses to acknowledge that sense can be given over to us by technicity in this manner: 'the origin of sense makes no sense...that which constitutes sense is senseless' 
(Derrida \& Stiegler 2002: 108-9). In concurrence with Bennington, the Derridean response to an organology of sense, as Ben Roberts sums up, is the question of 'how is theoretical and historical knowledge of "technics" possible, given that...technics is first of all what makes theory and history possible?' (Roberts 2005). However, this 'theoretical and historical knowledge' is always thwarted by its individuation, a différance between externalised and adopted experience. This organological origin of sense is what is at stake in the accusations of positivism in Stiegler's re-figuration of différance. Technics opens up a play between the determination of memory in inorganic matter, and the indetermination of its re-interiorisation according to a logic of différance. There are rules or conditions of access to 'knowledge', defined by the inheritance of tradition formed by epiphylogenesis that forms an individual world, but these rules open access to the indeterminate: "[t]he improbable cannot be reduced; there is always an excess over the programmatic, an excess that animates it in the first place' (Stiegler 2001: 261).

This means that knowledge as an individuation process cannot be reduced to positivism, because it is always an adoption of an organological horizon that conditions the rules of its emergence, as a criteria of selection (Stiegler 2010b: 87-8; Stiegler 2011b: 39). Further, the condition of this criteria of selection is not neutral, something Stiegler thinks through the pharmakon. Re-reading Derrida on this point, where 'the pharmakon and writing are thus always involved in questions of life and death' (Derrida 1981: 105), of curative and poisonous tendencies, Stiegler applies this logic to technics as a whole. According to the historical development of the way it sutures human existence, the poisonous and curative tendencies of the pharmakon are articulated differently in different technical systems. This can thought by understanding the two pharmacological tendencies as adaption and adoption. Darwinian notions of adaption cannot be applied to human existence (Moore 2013: 21 ), as the chance variation involved in the differentiation of organisms and species involve no intentionality (something that unfolds according a logic of différance). The human regime of individuation is characterised not by adaption, but by adoption: the deliberate taking on of new technical supplements, transforming the social systems that they support. This means 'natural selection has 
given way to artificial selection' (Stiegler 2015a: 31). This adoption is what differentiates human différance from that of the living: the human projects its unity forward through the technical support of its individuation (Stiegler 2011a: 23-4). Nevertheless, this does not mean that the human is completely separated from adaption. This tendency can be induced by the short-circuiting of adoption by stupidity, the inability to transform and singularise this projection into the future:

'learning-internalization is a process of adoption. As the inverse of this learning and apprenticeship, and of these adoptions, transmissions and transindividuations, segmented markets operating via "age groupings" are promoted by pharmaka submitted to the adaptive processes in which consumption naturally consists: that which is consumed cannot be adopted, since on the contrary it must be immediately disposable' (Stiegler 2013b: 130).

Taking place through this pharmacological uncertainty, human individuation does not consist in an absolute separation from the arche-writing of life, and a privilege with regard to the inorganic as Colony claims, but instead emerges out of the relation to the inorganic through a different form of individuation that is a new relation to its milieu, a relation of adoption that can never escape the dangers of adaption.

The Human as the Site of the Political: Différance, Noo-Politics, and Becoming Non-Inhuman

Hence, Stiegler's non-positivist reading of technics opens up onto a politics of becoming human. The ramifications of this politics arises from the doubling of différance. Three such ramifications can be identified in conclusion. ${ }^{\times}$First, he uses this historicisation of différance to understand different regimes of human individuation, based on how individuation relies on technical supports, constituting an organological genealogy. This makes possible a genealogy of the ways in which the logic of différance threatens the possibility of adopting a new human future, with the imposition of the adaptive dimension of the pharmakon. This requires a break from différance as life, as it is conditioned by the tendential dynamics of technical systems, and is therefore constituted by the transductive and differential relationship between psychic, social and technical individuations. The line between the 
human and life is constantly re-drawn and re-constituted. The political consists in the identification of how adaption and adoption condition the creation of new norms in this regime of individuation (Stiegler 2010a: 82). This is precisely why Stiegler speaks of a becoming non-inhuman: we are never fully human, and are always performatively reconstituting the 'shibboleth' between animality and humanity, because we are irreducibly both (Stiegler 2009: 157, 162). This continual (re)constitution means 'there is something not shown, that there is ciphered singularity: irreducible to any concept, to any knowledge, even to a history of tradition,' that nevertheless must continually be shown in the empirical articulations of this transcendental logic (Derrida 2005b: 33). Stiegler therefore challenges any simple institution of the human, by positing the pharmacological figure of the non-inhuman that adopts new norms, which is always threatened by its inhuman dissolution in adaption (Barker 2012: 14-15). Différance, when understood through transduction of regimes of individuation, can be connected to the logic of normativity, without reducing normativity to teleology. It is only through his mobilisation of the work of Leroi-Gourhan, Simondon, and Canguilhem that Stiegler can make this point.

Second, a critique of consumerism arises from the claim that the adoption of norms can be short-circuited by the imposition of modes of existence structured around adaption, that does not allow the time or the space for their transformation. This links the concept of différance to the material ways in which different individuation processes are produced by connected biological, social, and technical systems. As a synchronic movement towards the reduction of all processes to their metastable relations without diachronic transformation, adaption is a dominant tendency within the regime of hyper-industrial consumption (Stiegler 2010a: 103). The integration of economic, technical and social systems submits individuation to the imperatives of financialisation, and the adaption to the production of new needs this regime requires in order to produce value (Stiegler 2010a: 82-3). This means that ways of life, formerly connected to the transformative adoption of techniques are not reinteriorised by individuals, having become the target for consumption. Instead of adopting tradition by transforming it through différance, we are increasingly adapting to the imperative of consumption without this critical transformation. Human existence 'becomes entropic: it destroys that which is 
precisely the goal of all these criteriologies,' this goal being the opening and adoption of a noninhuman future (Stiegler 2013b: 129).

The materiality of the human regime of différance is central to this understanding of the divestment of the individual of the time to adopt savoir faire and savoir vivre (Stiegler 2011a: 62). What Stiegler refers to as 'generalised proletarianisation' is this loss of skilled knowledge, which began with the factory worker in the industrial revolution, and has expanded to the knowledge of to how live one's life. ${ }^{\mathrm{x}}$ The incessant multiplication of imperatives to consume encourages the indulgence in purely adaptive behaviour and the obliteration of the individual time of delay, something enabled by real time technologies that reduce the time of critical interiorisation that transforms pre-individual funds. This is enforced through the spread of new criteria for the process of retention, which are massified by the homogenisation of collective secondary retentions, supported by technical memory, and exacerbated by the expansion of automation in the processes of the content of the various modes of human existence, anticipating and calculating what is always a deferred and un-unified future (Stiegler 2014c: 87-8; 2015a: 224-27). Adaption is the enforcement of unity upon becoming, an inhuman tendency that counters the non-inhuman openness of the future. This is the point at which Stiegler's reading of différance is at its weakest. Despite the doubling of différance which allows it to refer to two separate individuation processes, articulated along different relations to preindividual funds, this political use relies on the reduction of différance to instantaneous transmission that reduces the time of critical reflection. This is something that Derrida rightly resists in the interview between the two: 'what we call real time is simply an extremely reduced 'différance', but there is no purely real time because temporalization itself is structured by a play of retention or of protention, and consequently, of traces' (Derrida \& Stiegler 2002: 129).

Nevertheless, the hegemony of what Stiegler refers to as industrial temporal objects does impinge on this structure of retentions and protentions that are bound within psychic individuation, because they draw from a pre-individual fund that is overdetermined by technical objects. The organological connection of social, technical, and biological organs enables this movement, as the becoming of the physical circuits of the brain are directly inscribed upon by technical processes of 
individuation. Just as, for example, reading requires a particular cerebral arrangement, new forms of technological objects today are reorganising the brain once again. The political ramifications of the invention of writing and the spread of literacy are being overturned, as the organological condition of the human is being exploited, transforming the psychopower of wants and needs into a neuropower that capitalises on the ability to directly intervene in the behaviour and formation of cerebral circuits (Stiegler 2010b: 190-1). Failing to acknowledge that we are at a profound event or juncture in the technical articulation of human différance or individuation, will miss what Stiegler contributes to contemporary political debates: that the intensification of the tendency towards the standardisation of modes of behaviour is reducing existence to one characterised by dis-individuation, a mode of différance which does not allow the differentiation of the future. What Stiegler refers to as 'NooPolitics' is the organisation of modes of existence that keep the human regime of individuation open by allowing adoption and critical transformation of pre-individual funds, rather than submitting to an adaptive tendency that dissolves the works of culture (Stiegler 2010b: 180-81). Stiegler argues that the task of politics is to keep the future of the non-inhuman open to adoptive transformation, rather than adaptive inhumanism. It is the transformative power of adoption that can alleviate the adaptive disindividuation at work in the biopolitical and psycho-political practices of marketing, which induce stupidity and the inability to transform the future (Stiegler 2015a: 235-37).

At this point, Stiegler's work operates at an abstract level, advocating a politics of memory, attention, spirit, and 'negative entropy' as a critique of hyper-industrial consumption. However, we can see a third political ramification of his reading of Derrida. For our purposes here, the value of Stiegler's work is not to be found in explicit political proposals, but in the fact that it allows a widening of the perspective on the politics of deconstruction, beyond the impasses of messianism and the deferral of the decision. He relates the political to the necessity of the decision to adopt new normative forms of existence in particular determined contexts, while keeping this future open to the indeterminate through the transformative dimension of adoption $(2015 \mathrm{c}: 91)$. The promise of the future does not arise from a primary 'ordeal of undecidability' (Derrida 1994: 94), but from a set of determined conditions from which the undecidable future must be created through adoption, against the 
hegemonic imposition of adaption (Stiegler 2013a: 336-37). Below the criticism of consumption and the advocation of certain general models for politics, Stiegler provides a systematic understanding of how technical objects constitute the human in particular temporal and spatial realities. It is the incalculable adoption of, and projection forward from a determined situation that harbours the potential for transforming the future. Hence, Stiegler imposes a distinction between becoming and the future, of which the latter must be produced through adoption (Stiegler 2015b). This forms the political as a constant becoming non-inhuman, making decisions on a future that is always a collective fiction, and therefore something to be adopted, and not a becoming to merely be adapted to (Stiegler 2011a: 148).

This political position is only enabled by Stiegler's reading of Derridean différance, which connects the openness of the human future to an ever present technical support. As I have argued, this can only be understood through Stiegler's extension of the work of Leroi-Gourhan, Simondon, and Canguilhem. That is, he thinks différance as present both in life and in the human-technical relationship, and as split into regimes, of which life in general and the human form of psycho-social individuation are distinct but related forms. This inaugurates a different form of pathology and normativity in the human, where the technical opens up both an indeterminate future to be adopted, and the pathological inducement of adaption, calculating and closing off this future. Noo-Politics concerns establishing regimes of adoptive individuation that constructs new forms of human existence. The value of Stiegler's work is that it poses a difficult and critical form of humanism in this Noo-Politics of becoming non-inhuman. As I have demonstrated, moving beyond Derrida, Stiegler wants to focus on the specific, pharmacological and material basis of these problems, and the particular decisions they force upon us. Stiegler's political project must, therefore, be seen in this light; the différance of becoming non-inhuman out of a pre-individual technical milieu, distinguished from the différance of life itself. 


\title{
Notes
}

\begin{abstract}
${ }^{i}$ Stiegler argues that connections must be made between Simondon and Derrida's work today, however the relationship between the two is not clear cut, and there is ample room for further work in this area. Besides the connections made in this piece on life, Stiegler makes remarks that suggest the Simondonian concepts of 'resonance' and transindividuation bear structural and conceptual similarities to différance and supplementarity, which belies the necessity of understanding a deeper link between the work of Simondon and Derrida (Stiegler: 2006; Stiegler, Roberts, Gilbert \& Hayward 2012: 179). The relationship between Stiegler, LeroiGourhan, and Derrida has already received some critical treatment (Johnson 2013), but the connection of
\end{abstract} Stiegler and Derrida to Canguilhem is an area awaiting exploration.

ii Différance should not be seen as homogeneously accepted across Derrida's interpreters, as it is Stiegler's reading in particular that is being put forward here. For just three examples of contrasting readings, one might look to Hägglund's view that Derrida's work is fundamentally atheistic, precisely because différance delimits any claim to the absolute (Hägglund 2008); John D. Caputo's argument that Derrida's work exhibits a complex intertwinement with negative and apophatic theological dimension of différance (Caputo 1997); or, Rodolphe Gasché's argument that différance is coherent with the philosophical task of criticising reflection, but nevertheless maintains a system that is both open and coherent (Gasché 1986).

iii Stiegler's reading of Derrida in The Fault of Epimetheus is largely concentrated around the essay 'Différance' and Of Grammatology. Across his oeuvre however, he engages with many Derridean concepts such as 'shibboleth', 'iterability' the 'pharmaka' and 'bêtise' (See Stiegler 2009; 2013b; 2015b) While focused on the isolated topic of différance and life here, there is space for an investigation of Stiegler's relationship to Derrida's corpus as a whole. For important work already published on this relationship see that of Ben Roberts (2005) \& Ross (2013).

${ }^{\text {iv }}$ This chapter was originally published as a review of The Fault of Epimetheus (Bennington 1996).

${ }^{v}$ While it is beyond the scope of what is being argued here, in more recent work Stiegler defines life in terms of entropy and negative entropy, something that is also transformed by the intervention of technics in human existence (Stiegler 2015a).

vi This separation between genetic and non-genetic memory characterises Molecular Biology's central dogma.

${ }^{\text {vii } V}$ Vitale highlights a crucial passage for Derrida's reading, where Jacob writes of the genetic material of heredity: 'The model that best describes our knowledge of heredity is indeed that of a chemical message....an alphabet like that of the Morse code. Just as a sentence represents a segment of text, so a gene corresponds to a segment of nucleic acid. In both cases, an isolated symbol means nothing; only a combination has any 'sense'... The transformation of a nucleic acid sequence into a protein sequence is like the translation of a message received in Morse that does not make sense until it is translated, into English, for example. This is done by means of a 'code' that provides the equivalence of signs between the two 'alphabets" (Vitale 2014: 108; Jacob 1974: 275)

viii For responses that also consent to, or present this view, see the work of Beardsworth (1998), Bradley (2011: 120-142), Roberts (2005) \& Vaccari (2009).

${ }^{\text {ix }}$ The concept of the pharmaka is taken from Derrida's reading of Plato in the Phaedrus, but expanded to refer to the technical constitution of the human (Derrida 1981; Stiegler 2013b: 19-22).

${ }^{x}$ While the focus here is upon how Stiegler's philosophy opens up a consideration of the indeterminate future of the human as political, what is not addressed in more detail is the way in which memory and the control of its technical basis is a site for political contestation. For more on this in particular see the work of Beardsworth (1995), Roberts (2006), and Sinnerbrink (2009), or for broader summaries of Stiegler's politics, see Abbninett (2015), Beardsworth (2010), Crogan (2010), and Vesco (2015).

${ }^{x i}$ Proletarianisation refers to Stiegler's adoption of the Simondonian reading of Marx, where the development of machine production and the division of labor divested workers of skills (savoir faire) that were interiorised and learnt prior to machinic production. Stiegler's thesis is that under consumerism this tendency has extended into everyday life and we are currently being divested of knowledge of how to live our lives (savoir vivre). For an expanded summary of proletarianisation, see the work of Hutnyk (2013) 


\section{References}

Abbinnett, Ross (2015) 'The Politics of Spirit in Stiegler's Techno-Pharmacology,' Theory, Culture \& Society, $32: 4$, pp. 65-80.

Barker, Stephen (2012), 'Post-Scriptum: Pharmacodemocracy', Derrida Today, 5.1, pp. 1-20.

Beardsworth, Richard (1995), 'From a Genealogy of Matter to a Politics of Memory: Stiegler's Thinking of Technics', Tekhnema 2.

Beardsworth, Richard (1998), 'Thinking Technicity', Cultural Values, 2:1, pp. 70-86.

Beardsworth, Richard, (2010), 'Technology \& Politics: A Response to Bernard Stiegler,' Cultural Politics 6:2, pp. 181-99.

Bennington, Geoffrey (1996), 'Emergencies', The Oxford Literary Review, 18, pp. 175-216.

Bennington, Geoffrey (2000), Interrupting Derrida, UK: Routledge.

Canguilhem, Georges (1991), The Normal and the Pathological, trans. Caroyln Fawcett, Robert Cohen, USA: Zone Books.

Canguilhem, Georges (2008), 'Machine and Organism', in Knowledge of Life, trans. Stefanos Geroulanos \& Daniela Ginsburg, ed. Paola Maratti \& Todd Meyers, USA: Fordham University Press, pp. 75-97.

Caputo, John D. (1997), The Prayers and Tears of Jacques Derrida: Religion Without Religion, USA: Indiana University Press.

Chabot, Pascal (2013) The Philosophy of Simondon: Between Technology and Individuation, trans. Aliza Krefetz and Graeme Kirkpatrick, UK: Bloomsbury.

Colony, Tracy, (2011), 'Epimetheus Bound: Stiegler on Derrida, Life, and the Technological Condition', Research in Phenomenology, 41:1, pp. 72-89.

Combes, Muriel, (2013) Gilbert Simondon and the Philosophy of the Transindividual, trans. Thomas LaMarre, USA: MIT University Press.

Crogan, Patrick (2010), 'Bernard Stiegler: Philosophy, Technics, and Activism', Cultural Politics 6:2, pp. 13356.

Derrida, Jacques (1972), 'Différance', in Margins of Philosophy, trans. Alan Bass, USA: University Of Chicago Press, pp. 1-27.

Derrida, Jacques (1976), Of Grammatology, trans. Gayatry Chakravorty Spivak, USA: The John Hopkins University Press.

Derrida, Jacques (1981), 'Plato's Pharmacy', in Dissemination, trans. Barbara Johnson, UK: The Athlone Press, pp. 61-172.

Derrida, Jacques (1994), Spectres of Marx: The State of Debt, the Work of Mourning, \& the New International, trans. Peggy Kamuf, UK: Routledge.

Derrida, Jacques (2005a), Of Touching - Jean-Luc Nancy, trans. Christine Irizarry, USA: Stanford University Press.

Derrida, Jacques (2005b), 'Shibboleth: For Paul Celan', in Sovereignties In Question: The Poetics of Paul Celan, ed. by Thomas Dutoit, Outi Pansen, trans. by Joshua Wilner. USA: Fordham University Press, pp. 164.

Derrida, Jacques \& Stiegler, Bernard (2002), Ecographies of Television, trans. Jennifer Bajorek, UK: Polity. Gasché, Rodolphe (1986), The Tain of the Mirror: Derrida and the Philosophy of Reflection, USA: Harvard University Press.

Hutnyk, John (2013), 'Proletarianisation', New Formations, 77, pp. 127-149.

Jacob, Franćois (1974), The Logic of Life: A History of Heredity, trans. Betty E. Spillman, USA: Pantheon Books.

James, Ian (2010), 'Bernard Stiegler \& The Time of Technics', Cultural Politics, 6:1, pp. 207-27.

James, Ian (2013), 'Technics and Cerebrality,' in Christina Howells \& Gerald Moore (ed.) Stiegler \& Technics, UK: Edinburgh University Press, pp. 69-84.

Johnson, Christopher (2013), 'The Prehistory of Technology: On the Contribution of Leroi-Gourhan,' in Christina Howells and Gerald Moore (ed.) Stiegler \& Technics, UK: Edinburgh University Press, pp. 34-52. 
Leroi-Gourhan, Andre (1993), Gesture \& Speech, trans. Anna B. Berger USA: MIT Press.

Lewis, Michael (2013), 'Of A Mythical Philosophical Anthropology: The Transcendental and the Empirical in Technics \& Time', in Christina Howells \& Gerald Moore (ed.) Stiegler \& Technics, UK: Edinburgh University Press, pp. 53-68.

Moore, Gerald (2013), 'Adapt and Smile or Die! Stiegler Among the Darwinists', in Christina Howells \& Gerald Moore (ed.) Stiegler \& Technics, UK: Edinburgh University Press, pp. 17-33.

Roberts, Ben (2005), 'Stiegler Reading Derrida: The Prosthesis of Deconstruction in Technics', Postmodern Culture, 16:1, last accessed 10th November 2015: http://pmc.iath.virginia.edu/text-only/issue.905/16.1roberts.txt

Roberts, Ben (2006), 'Cinema as Mnemotechnics: Bernard Stiegler and the 'Industrialization of Memory", Angelaki 11:1, pp. 55-63.

Ross, Daniel (2013), 'Pharmacology and Critique After Deconstruction', in Christina Howells \& Gerald Moore (ed.) Stiegler \& Technics, UK: Edinburgh University Press, pp. 243-258.

Simondon, Gilbert (2005), L'individuation à la lumière des notions de form et d'information, France: Éditions Jérôme Millon.

Simondon, Gilbert (2009), 'The Position of the Problem of Ontogenesis', trans. Gregory Flanders, Parrhesia, 7, pp. 4-16.

Sinnerbrink, Robert (2009), 'Culture Industry Redux: Stiegler and Derrida on Technics and Cultural Politics', Transformations 17.

Stiegler, Bernard (1998), Technics \& Time 1: The Fault of Epimetheus, trans. Richard Beardsworth, USA: Stanford University Press.

Stiegler, Bernard (2001), 'Derrida \& Technology: Fidelity at the Limits of Deconstruction and the Prosthesis of Faith', trans. Richard Beardsworth, in Tom Cohen (ed.), Derrida \& The Humanities: A Critical Reader, UK: Cambridge University Press, pp. 238-270.

Stiegler, Bernard (2006), 'Desire \& Knowledge: The Dead Seize the Living', trans. George Collins \& Daniel Ross, last accessed 10th November 2015: www.arsindustrialis.org/desire-and-knowledge-dead-seize-living. Stiegler, Bernard (2009), Technics \& Time 2: Disorientation, trans. Stephen Barker, USA: Stanford University Press.

Steigler, Bernard (2010a), For a New Critique of Political Economy, trans. Daniel Ross, UK: Polity.

Stiegler, Bernard (2010b), Taking Care of Youth and the Generations, trans. Stephen Barker, USA: Stanford University Press.

Stiegler, Bernard (2011a), Disbelief \& Discredit Vol. 1: The Decadence of Industrial Democracies, trans. Daniel Ross, UK: Polity.

Stiegler, Bernard (2011b), Technics \& Time 3: Cinematic Time \& the Question of Malaise, trans. Stephen Barker, USA: Stanford University Press.

Stiegler, Bernard (2013a), Pharmacologie du front national: Suivi du vocabulaire d'Ars Industrialis, France:

Flammarion.

Stiegler, Bernard (2013b), What Makes Life Worth Living: On Pharmacology, trans. Daniel Ross, UK: Polity. Stiegler, Bernard (2014a) 'Afterword: Web Philosophy', trans. Harry Halpin \& Louis Morrel in Harry Halpin \& Alexandre Monnin (ed.), Philosophical Engineering: Toward a Philosophy of the Web, UK: Wiley Blackwell, pp. 187-198.

Stiegler, Bernard (2014b), Symbolic Misery Vol 1: The Hyper-Industrial Epoch, trans. Daniel Ross, UK: Polity.

Stiegler, Bernard (2015a), La société automatique vol 1: l'Avenir du travail, France: Fayard.

Stiegler, Bernard (2015b), 'Power, Powerlessness, Thinking, and Future', trans. Daniel Ross, LA Review of Books, October 18, 2015.

Stiegler, Bernard (2015c), States of Shock: Stupidity and Knowledge in the 21st Century, trans. Barnaby Norman.

Stiegler, Bernard, Ben Roberts, Jeremy Gilbert \& Mark Hayward (2012), 'A Rational Theory of Miracles: On Pharmacology and Transindividuation', trans. Ben Roberts, New Formations, 77, pp. 164-184. 
Vaccari, Andre (2009), 'Unweaving the Program: Stiegler and the Hegemony of Technics', Transformations, 17.

Vesco, Shawna (2015), 'Collective Disindividuation and/or Barbarism: Technics and Proletarianization,' Boundary 2, 42:2, pp. 85-104.

Vitale, Francesco (2014), 'The Text and the Living: Jacques Derrida between Biology and Deconstruction', The Oxford Literary Review, 36:1, pp. 95-114. 